\title{
Analysis of Recent Serotype O FootandMouth Disease Viruses from Livestock in Kenya: Evidence of Four Independently Evolving Lineages
}

Wekesa, S. N.; Muwanika, V. B.; Siegismund, H. R.; Sangula, A. K.; Namatovu, A.; Dhikusooka, M. T.; Tjørnehøj, Kirsten; Balinda, S. N.; Wadsworth, J.; Knowles, N. J.

Total number of authors:

11

Published in:

Transboundary and Emerging Diseases

Link to article, DOI:

10.1111/tbed.12152

Publication date:

2015

Document Version

Peer reviewed version

Link back to DTU Orbit

Citation (APA):

Wekesa, S. N., Muwanika, V. B., Siegismund, H. R., Sangula, A. K., Namatovu, A., Dhikusooka, M. T.,

Tjørnehøj, K., Balinda, S. N., Wadsworth, J., Knowles, N. J., \& Belsham, G. (2015). Analysis of Recent Serotype

O FootandMouth Disease Viruses from Livestock in Kenya: Evidence of Four Independently Evolving Lineages.

Transboundary and Emerging Diseases, 62(3), 305-314. https://doi.org/10.1111/tbed.12152

\section{General rights}

Copyright and moral rights for the publications made accessible in the public portal are retained by the authors and/or other copyright owners and it is a condition of accessing publications that users recognise and abide by the legal requirements associated with these rights.

- Users may download and print one copy of any publication from the public portal for the purpose of private study or research.

- You may not further distribute the material or use it for any profit-making activity or commercial gain

- You may freely distribute the URL identifying the publication in the public portal 


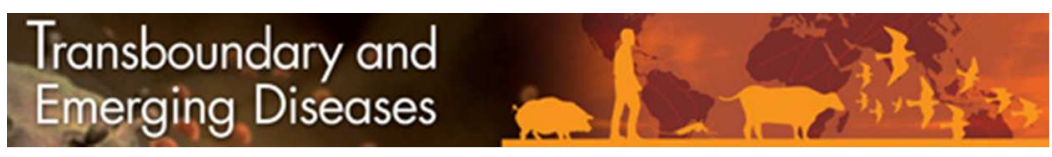

\section{Analysis of Recent Serotype O Foot-and-Mouth Disease Viruses from Livestock in Kenya: Evidence of Four Independently Evolving Lineages}

\begin{tabular}{|c|c|}
\hline Journal: & Transboundary and Emerging Diseases \\
\hline Manuscript ID: & TBED-OA-123-13.R1 \\
\hline Manuscript Type: & Original Article \\
\hline Date Submitted by the Author: & 16-Jul-2013 \\
\hline Complete List of Authors: & $\begin{array}{l}\text { Wekesa, Sabenzia; Foot-and-Mouth Disease Laboratory, Ministry of } \\
\text { Livestock Development, Veterinary Services Department; College of } \\
\text { Agricultural and Environmental Sciences, Makerere University, Department } \\
\text { of Environmental Management } \\
\text { Muwanika, Vincent; College of Agricultural and Environmental Sciences, } \\
\text { Makerere University, Department of Environmental Management } \\
\text { Siegismund, Hans; University of Copenhagen, Depertment of Biology } \\
\text { Sangula, Abraham; Foot-and-Mouth Disease Laboratory, Ministry of } \\
\text { Livestock Development, Veterinary Services Department } \\
\text { Namatovu, Alice; College of Veterinary Medicine, Animal Resources and } \\
\text { Biosecurity, Makerere University, Department of Biotechnical and } \\
\text { Diagnostic Sciences } \\
\text { Dhikusooka, Moses; National Animal Disease Diagnostics and Epidemiology } \\
\text { Centre, Ministry of Agriculture Animal Industry and Fisheries, ; College of } \\
\text { Agricultural and Environmental Sciences, Makerere University, Department } \\
\text { of Environmental Management } \\
\text { Tjornehoj, Kirsten; Danish Techincal University, National Veterinary } \\
\text { Institute } \\
\text { Balinda, Sheila; College of Agricultural and Environmental Sciences, } \\
\text { Makerere University, Department of Environmental Management } \\
\text { Wadsworth, Jemma; The Pirbright Institute, Ash Road, Pirbright, Woking, } \\
\text { Knowles, Nick; The Pirbright Institute, Ash Road, Pirbright, Woking, } \\
\text { Belsham, Graham; Technical University of Denmark, National Veterinary } \\
\text { Institute }\end{array}$ \\
\hline Subject Area: & $\begin{array}{l}\text { Kenya, Foot-and-mouth disease, Serotype O FMDV, East Africa, Topotype, } \\
\text { Outbreaks }\end{array}$ \\
\hline
\end{tabular}

\section{SCHOLARONE $^{\text {ix }}$ \\ Manuscripts}




\title{
Analysis of Recent Serotype O Foot-and-Mouth Disease Viruses from Livestock in Kenya: Evidence of Four Independently Evolving Lineages
}

S. N. Wekesa ${ }^{1,2}$, V. B. Muwanika ${ }^{2}$, H. R. Siegismund ${ }^{3}$, A. K. Sangula ${ }^{1}$, A. Namatovu ${ }^{4}, 5$, M.T. Dhikusooka $^{2,4}$, K. Tjørneh $\varnothing^{6}{ }^{6}$, S. N. Balinda ${ }^{2}$, J. Wadsworth ${ }^{7}$, N. J. Knowles ${ }^{7}$, G.J. Belsham ${ }^{6 *}$

${ }^{1}$ Foot-and-Mouth Disease Laboratory, Ministry of Livestock Development, P. O. Box 18021, Embakasi, Nairobi, Kenya

${ }^{2}$ Department of Environmental Management, College of Agricultural and Environmental Sciences, Makerere University, P. O. Box 7062/7298 Kampala, Uganda

${ }^{3}$ Department of Biology, University of Copenhagen, Ole Maaløes Vej 5, DK-2200, Copenhagen N, Denmark

${ }^{4}$ National Animal Disease Diagnostics and Epidemiology Centre, Ministry of Agriculture Animal Industry and Fisheries, P. O. Box 513, Entebbe, Uganda

${ }^{5}$ Department of Biotechnical and Diagnostic Sciences, College of Veterinary Medicine, Animal Resources and Biosecurity, Makerere University, P. O. Box 7062, Kampala, Uganda

${ }^{6}$ National Veterinary Institute, Technical University of Denmark, Lindholm, DK 4771, Kalvehave, Denmark

${ }^{7}$ The Pirbright Institute, Ash Road, Pirbright, Woking, Surrey, GU24 0NF, United Kingdom.

\author{
*Correspondence \\ Graham. J. Belsham \\ National Veterinary Institute, Technical University of Denmark \\ Lindholm, DK 4771, Kalvehave, Denmark \\ Tel.: +453588 7985 \\ Fax: + 4535887901 \\ E-mail: grbe@ vet.dtu.dk
}




\begin{abstract}
Summary
Foot-and-mouth-disease (FMD) is endemic in Kenya where four serotypes (O, A, SAT 1 and SAT 2) of the virus are currently in circulation. Within 2010 and 2011, the National Laboratory recorded an increase in the number of FMD outbreaks caused by serotype $\mathrm{O}$ virus. The characteristics of these viruses were determined to ascertain whether these were independent outbreaks or one single strain spreading throughout the country. The sequences of the complete VP1 coding region were analyzed from viruses sampled within different areas of Kenya during 2010 and 2011. The results indicated that the 2010 and 2011 outbreaks in Kenya were independent from each other. By comparison with earlier type O isolates from Eastern Africa, it was apparent that the outbreaks were caused by viruses from three different lineages of topotype EA-2 and a fourth virus strain belonging to topotype EA-4. The topotypes EA-1 and EA-3 were not detected from these outbreaks. Implications of these results for FMD control in Eastern Africa are discussed.
\end{abstract}

Keywords: Kenya; foot-and-mouth-disease; serotype O FMDV; East Africa; topotype; outbreaks 


\section{Introduction}

Foot-and-mouth disease (FMD) affects both domestic and wild cloven-hoofed animals such as cattle, pigs, sheep, and goats plus more than 70 species of wildlife (Alexandersen and Mowat, 2005; Thomson et al., 2003). The disease is clinically characterized by fever, lameness, and vesicular lesionsvesicles on the tongue, feet, snout, and teats of susceptible species (Kitching, 2002). FMD has been known since the sixteenth century as an important threat in the cattle industry and has continued to $\underline{\text { is }}$ be one of the world's most economically important livestock diseases_. Losses due to FMD can bewith indirect losses due to trade embargos embargos on livestock and livestock products or and direct oneeffects -such as reduced milk yields, weight loss, abortions, prenatal mortality and loss of cart power in draught animals (James and Rushton, 2002). Improved control of the diseasethe disease -may contribute to poverty reduction and increased economic growth in developing countries (Perry and Rich, 2007) such as Kenya where the disease is endemic.

The causative agent-of the disease, foot-and-mouth disease virus (FMDV), occurs in seven immunologically and genetically distinct serotypes O, A, C, Asia 1, SAT 1, SAT 2, SAT 3 and multiple variants exist within each serotype (Grubman and Morgan, 1986; Knowles and Samuel, 2003) ${ }_{-}^{-}$These serotypes can be distinguishedable both serologically and by nucleotide sequencing. Vaccination against one serotype does not cross-protect-against other serotypes, , thus-necessitating vaccination against all circulating each of the-serotypes-circulating. in an area or an outbreak. FurthermoreAdditionally, FMDV has a high potential for genetic and antigenic variation, thishencewhich createsing the need to constantly match vaccines to the circulating field viruses (Domingo et al., 2003).

The FMDV genome is a positive-sense single-stranded RNA molecule with a length of approximately 8400 nucleotides (nt) long that belongs to the genus Aphthovirus within the Picornaviridae family (Belsham, 2005). The genome encodes a polyprotein which is processed to the virus structural proteins (SP) designated VP1 (1D), VP2 (1B), VP3 (1C), and VP4 (1A) and multiple non-structural (NS) proteins (Rueckert, 1984). Within the viral RNA, Tthe VP1 coding region has been found to beis the most variable, hence many studies of evolutionary relationships between FMDV strains and serotypes are based on VP1 sequences have sequenced this part of the genome in order to determine and understand evolutionary relationships between FMDV strains and serotypes-(Knowles and Samuel, 2003), and have. Based on these 
VP1 sequences, the serotypes have been grouped the serotypes into various epidemiologically and genetically distinct regional clusters in different regions of the world defined as virus lineages and topotypes in accordance with intra-lineage and intra-topotype nucleotide identity $\geq 92.5 \%$ and $\geq 85 \%$, respectively (Knowles and Samuel, 2003; Samuel and Knowles, 2001a).

Among the seven serotypes, FMDV O has been found to be dominant globally and has been responsible for some economically devastating outbreaks in countries which are normally free from FMDdisease-free such as the United Kingdom (Knowles et al., 2001; Samuel and Knowles, 2001b) and Japan (Hayama et al., 2012; Sakamoto and Yoshida, 2002). Similarly, in the region of East Africa (EA) where the disease is endemic, serotype $\mathrm{O}$ has been responsible for most outbreaks. Several recent studies have characterized these FMDV $\mathrm{O}$ isolates in EA and recommended inclusion of_a broader range of virus isolates in future analyses for a better approach to FMD control within the region (Ayelet et al., 2009; Balinda et al., 2010a; Habiela et al., 2010; Kasambula et al., 2012). These studies found four topotypes of this serotype namely, East Africa 1 (EA-1) to EA-4 circulating in this region with no evidence of additional introductions except for transboundary exchange of viruses between neighbouring countries within the region. In Kenya, most FMDV O strains isolated within the country since 2000 belong to topotypes EA-2, EA-3 and EA-4, while the locally produced vaccine that is currently in use is based on strain O K77/78 which was isolated in 1978 and is classified within topotype EA-1 (Balinda et al., 2010a). The use of this vaccine may contribute to inadequate disease control, yet the FMD control policy in Kenya is to use locally produced vaccines and animal movement control. So far, the Directorate of Veterinary Services (DVS) has not received complaints or had records of FMDV O post-vaccination outbreaks although it lacks resources to undertake consistent post-vaccination monitoring (PVM). However, it relies on vaccine potency testing results (involving vaccination and challenge), generated by the state vaccine quality control laboratory that is independent from the producer.

Apart from serotype O, other serotypes including A, SAT 1 and SAT 2 have also been recently in circulation (Namatovu et al., 2013), while previously, serotype $\mathrm{C}$ has also been identified within the region (Vosloo et al., 2002). However, serotype C was last isolated from Kenyan cattle in 2004 (Roeder, 2009; Sangula et al., 2011). 
During 2010 and 2011, there was an increase in the recorded number of FMD outbreaks in Kenya. From the use of virus isolation and antigen detection proceduresusing enzyme linked immunosorbent assays (ELISAs), the Kenyan National Laboratory found that 105 of the 265 districts in the country (40\%) had cases of FMD between January and December 2010 and this pattern continued into 2011. Among these, 74 districts $(70 \%)$ had been affected by serotype O FMDV, the highest annual occurrence of this serotype since the year 2000. It was not known whether these were independent outbreaks or if each case was part of a single outbreak that quickly spread to the various districts of the country. In a comparable occurrence, multiple FMD outbreaks were reported to have taken place-within a short period of time during 2008-2009 in neighboring Uganda were shown to belong to a single outbreak that rapidly spread and affected large areas (Kasambula et al., 2012).

Recently,_Balinda et al., (2010a) sequenced the VP1 coding region of 46 viruses of serotype O collected in Kenya between 1964 and 2008 and recommended a more widespread collection of viruses for appropriate vaccine development and better regional FMD control strategies. Now, in this study, the VP1 coding region sequences of recently (2010-2011) circulating serotype O FMDVs from various geographical areas of Kenya have been determined and analysed. The study was aimed at determining the characteristics of these VP1 sequences in order to understand the recent outbreak patterns.

\section{Materials and Methods}

\section{Source of viruses used in this study}

Epithelial samples were selected from the national FMD laboratory (FMDL), Embakasi, Kenya virus repository. These were field samples collected, from suspected clinical cases of FMD in cattle by goverment District Veterinary Officers (DVOs), between February 2010 and September 2011 for the purpose of serotype identification and mapping to guide FMD control strategies. The samples were preserved in 50\% glycerol-phosphate buffered saline (PBS) and transported on ice, in the shortest time possible, to the FMDL, where they were subsequently aliquoted and preserved at $-20^{\circ} \mathrm{C}$. Virus isolation in Baby Hamster Kidney (BHK) cells and FMDV antigen detection using enzyme linked immunosorbent assays (ELISAs) were routinely performed according to procedures in the OIE manual (OIE, 2012). For the purpose of this study, the samples were selected taking regional representation and quality of the material into consideration. Thus samples were selected from different districts representing the eight administrative 
regions (provinces) of the country, namely: Western, Nyanza, Rift-Valley, Central, Nairobi, Eastern, NorthEastern and Coast (Fig. 1). Viruses from a total of 35 samples collected between 1998 and 2011 have been isolated and sequenced in this study at the National Veterinary Institute, Technical University of Denmark, Lindholm (DTU Vet) and The Pirbright Institute, U.K. (Table 1). The sequences were analysed together with others from a previous study (Balinda et al., 2010a) and from the public sequence databases (Table 1).

\section{Virus Isolation}

$\underline{\text { At Lindholm and in Pirbright, for the purpose of sequencing, viruses were re-isolated on primary bovine }}$ thyroid (BTY) cells according to the OIE manual (OIE, 2012). Briefly, epithelia preserved in 50\% glycerolPBS at $-20^{\circ} \mathrm{C}$, were thawed at room temperature, weighed and ground using sterile sand, with a mortar and a pestle, in Eagles minimum essential media supplemented with protein hydrolysate, $2 \%$ fetal calf serum and antibiotics to make a $10 \%$ suspension. The suspensions were inoculated onto primary bovine thyroid (BTY) cells for 1 hour, followed by a change of media and then continued incubation. The cultures were observed for cytopathic effect (CPE) after 24 and 48 hours and harvested when CPE developed. Negative samples were further passaged onto fresh cells for another 48 hours.

\section{Total RNA Extraction and cDNA Synthesis}

At The Pirbright Institute, total RNA extraction and cDNA synthesis were done as described by Ayelet et al. (2009) and Habiela et al. (2010), while at DTU Vet these were done as follows:

Viral RNA was extracted from CPE positive cell culture harvests using the QIAmp ${ }^{\circledR}$ viral RNA mini kit (Qiagen) following the viral RNA mini spin protocol as described by the manufacturer, using $60 \mu \mathrm{l}$ of AVE buffer for elution (as supplied) and the RNA was stored at $-80^{\circ} \mathrm{C}$.

To synthesize cDNA, the RT master mix was made using PE Biosystems TaqMan RT reagents (part N8081234) in accordance with the manufacturer's instructions. Briefly $y_{2}$ for each reaction, $1.5 \mu 1$ of 10x TaqMan RT buffer (500 mM KCl, $100 \mathrm{mM}$ TrisHCl, pH 8.3), $3.3 \mu \mathrm{l}$ of $25 \mathrm{mM} \mathrm{MgCl} 2,3.0 \mu 1$ of dNTP (2.5 mM each), $0.5 \mu \mathrm{l}$ of $50 \mu \mathrm{M}$ random hexamers, $0.3 \mu \mathrm{l}$ of RNase inhibitor (20U/ $\mu 1)$ and $0.375 \mu 1$ of MultiScribe reverse transcriptase (100 U/ $\mu 1$, Moloney RT) were used making a total of $9 \mu \mathrm{l}$ per reaction. RNA samples $(6 \mu \mathrm{l})$ were added to the master mix to make $15 \mu \mathrm{l}$ per reaction and incubated at $48^{\circ} \mathrm{C}$ for $45 \mathrm{~min}$, and $95^{\circ} \mathrm{C}$ for $5 \mathrm{~min}$. The cDNA products were stored at $-20^{\circ} \mathrm{C}$. 


\section{Real time RT-PCR to detect FMDV RNA}

Quantitative RT-PCR was performed using TaqMan ${ }^{\circledR}$ Universal 2X PCR Master Mix (PE Biosystems). The TaqMan PCR was run as described previously (Reid et al., 2003) using the FMDV MultiII IRES primers (FMDV Multi II forward primer and FMDV Multi II reverse primer) and FMDV Multi II-288 probe (FAM-labelled). The reaction mixtures $(25 \mu \mathrm{l})$ contained $2.25 \mu \mathrm{l}$ of $10 \mathrm{pmol} / \mu \mathrm{l}$ forward primer, $2.25 \mu \mathrm{l}$ of $10 \mathrm{pmol} / \mu \mathrm{l}$ reverse primer, $1 \mu \mathrm{l}$ of $5 \mathrm{pmol} / \mu \mathrm{l}$ probe and $12.5 \mu \mathrm{l}$ of the universal master mix. This $18 \mu \mathrm{l}$-of this master mix was mixed with $7 \mu \mathrm{l}$ cDNA template_and t. The tubes were sealed with optical caps and, then incubated in a Mx3005P cycler (Stratagene) for 50 cycles; $50^{\circ} \mathrm{C} 2 \mathrm{~min}$ (UNG digest), $95^{\circ} \mathrm{C} 10 \mathrm{~min}$ (heat activation of TaqGold) and $50 \times\left(95^{\circ} \mathrm{C} 15 \mathrm{~s}\right.$ and $\left.60^{\circ} \mathrm{C} 60 \mathrm{~s}\right)$, then held at $4{ }^{\circ} \mathrm{C}$.

\section{RT-PCR to amplify and sequence FMDV VP1 coding sequence}

At The Pirbright Institute, these methods were done as described by Ayelet et al. (2009) and Habiela et al. (2010), while at (DTU Vet) as follows:

Samples which were shown to contain significant amounts of FMDV RNA ( $\mathrm{Ct}<32$ ) (Shaw et al., 2007) were selected for VP1 coding region amplification. The cDNA sequence was amplified using reverse primer 11-FPN 28 (5' GGGCCCAGGGTTGGACTC 3') and forward primer 11-FPN 29 (5' GCIGCIGACTACGCITACACYGC 3') (note, $\mathrm{I}=$ inosine and $\mathrm{Y}=\mathrm{C}$ and $\mathrm{T}$ ). These primer sequences-were flanked the region betweenfound between positions nt 3936 and 3169 inef the virus genome respectively and includesing the entire VP1 coding region. The primers were-and designed with reference to strain $\mathrm{O}$ UKG 35/2001, GenBank accession number AJ53914 (Mason et al., 2003).

The reaction mixture for each amplification $(50 \mu \mathrm{l})$ comprised RNAase free water $(25 \mu \mathrm{l}), 5.0 \mu \mathrm{l}$ 10X PCR buffer, $4.0 \mu \mathrm{l}$ of $25 \mathrm{mM} \mathrm{MgCl}_{2}, 0.4 \mu \mathrm{l}$ of $10 \mathrm{mM}$ dNTPs, $5.0 \mu \mathrm{l}$ of each primer $(10 \mathrm{pmol} / \mu \mathrm{l})_{2}$ and $5.0 \mu \mathrm{l}$ cDNA template andplus $20 \mathrm{U}$ of AmpliTaq Gold ${ }^{\circledR}$ DNA polymerase (Applied Biosystems). The PCR was run in a thermocycler (Gene Amp ${ }^{\circledR}$ PCR system 3700 version 3.0 - Applied Biosystems) using the touchdown method for 1 cycle; $95^{\circ} \mathrm{C} 5 \mathrm{~min}, 1$ cycle; $95^{\circ} \mathrm{C} 15 \mathrm{~s}, 5$ cycles; $55^{\circ} \mathrm{C} 30 \mathrm{~s}, 1$ cycle; $72^{\circ} \mathrm{C} 1 \mathrm{~min}$ 20s, 40 cycles; $\left(95^{\circ} \mathrm{C} 15 \mathrm{~s}, 50^{\circ} \mathrm{C} 30 \mathrm{~s}, 72^{\circ} \mathrm{C} 1 \mathrm{~min} .20 \mathrm{~s}\right), 1$ cycle; $72^{\circ} \mathrm{C} 7 \mathrm{~min}$ and $4{ }^{\circ} \mathrm{C}$ holding.

The PCR products (ca. 885 bp) were viewed by electrophoresis on $1.5 \%$ agarose gels (Seakem GTG agarose in $1 \mathrm{X}$ TAE - low EDTA buffer) at 120 volts for 1 hour in parallel with a molecular weight marker 
ФX 174-RF DNA (Amersham, Biosciences). Purification of the PCR products was achieved using the QIAquick PCR purification kit (Qiagen). Products for cycle sequencing were quantified using a NanoDrop ${ }^{\circledR} 1000$ Spectrophotometer (Thermo Scientific) and for each reaction, 10 - $13 \mathrm{ng}$ of amplicon was used. Cycle sequencing, in both directions, was performed using the Big dye Terminator V 3.1 kit (Applied Biosystems) and run on an automated DNA Sequencer (ABI PRISM 3700; Applied Biosystems).

\section{Sequence Analysis}

The nucleotide sequences in this study were edited using SeqMan Pro software (Lasergene package, DNAstar, Inc.). Serotypes of the generated sequences were identified and compared with previous data using the Basic Local Alignment Search Tool (BLAST) (www.ncbi.nlm.nih.gov). The sequences were aligned by MUSCLE incorporated in MEGA software version 5.05 (Tamura et al., 2011) and trimmed to 639 nucleotides comprising the complete VP1 coding region.

Substitution models were determined in the MEGA software. Codon positions included were $1 \mathrm{st}+2 \mathrm{nd}+3 \mathrm{rd}$. Maximum Likelihood fits of 24 different nucleotide substitution models were estimated and Akaike Information Criterion (AIC) estimated. Non-uniformity evolution rates were modeled using discrete gamma distribution (G). Thus, Tamura Nei substitution model with gamma distribution and invariable rates (I) $(\mathrm{TN} 93+\mathrm{G}+\mathrm{I})$ was chosen as the best that describes the substitution pattern (Tamura et al.., 2011). The evolutionary history was inferred using the Neighbor-joining method (Saitou and Nei, 1987) and a bootstrap consensus tree estimated from 1000 replicates (Felsenstein, 1985) taken to represent the evolutionary history of the taxa analyzed.

The sequences in this study were compared to selected serotype O Kenyan isolates from 1978 to 2009 and to isolates obtained from neighbouring countries during 1986-2009, using two 1983 isolates from Hong Kong and Indonesia as outgroups. The taxa were grouped into topotypes defined by an intra-topotype nucleotide identity within the VP1 coding sequence of $>85 \%$ (Knowles and Samuel, 2003; Samuel and Knowles, 2001a).

\section{Results}

Thirty five FMD viruses wereall having been successfully isolated ien celltissue culture and tested positive for serotype O FMDV usingen antigen ELISAs. Virus harvests were also shown to contain significant 
amounts of FMDV RNA by real time RT-PCR assays $(\mathrm{Ct}<32)$. ; hence were selected for The VP1 coding region from each of these samples was amplified by RT-PCReation and subsequentlysequenced. BLAST searches usingef the VP1 coding region of these sequences confirmed that these were of serotype O FMDV in each case. Generally, aApart from one, all the other 2010-2011 viruses sequenced in this study were distributed among three distinct lineages (with each lineage having $\geq 7.5 \%$ differences in nucleotide sequence within the VP1 coding region) and were, classified within the EA-2 topotype (labeled as lineages A, B and C in Fig. 2). In a Neighbor-joining tree, tThese lineages grouped, in a Neighbor-joining tree, together with viruses from Uganda that had been collected in 2004-2006 (Fig. 2). The one other virus (K72/2010) belonged to the EA-4 topotype (labeled as lineage D in Fig. 2), originated from district 14 (Fig. 1) and grouped together with some earlier Ethiopian and Ugandan viruses. This virus made up an independently evolving sub-lineage within this topotype with nucleotide differences of about $11 \%$ and $9 \%$ compared to the Ethiopian and Ugandan viruses, respectively.

Lineage A, within the EA-2 topotype (Fig. 2), incorporated nine viruses from this study, including K31/2011 and K249/2010. These viruses had about 97\% intra-topotype nucleotide identity within the VP1 coding sequence. They were collected between December 2010 and April 2011 (Table 1) from six districts (Siaya, Nyandarua, Thika, Baringo, Rongai and Koibatek) located in three different provinces (Central, Rift Valley and Nyanza) (Fig. 1). This group differed in their nucleotide sequence from lineages B and C by about $12 \%$ and $10-11 \%$ respectively.

Lineage C, in the EA-2 topotype, included nine isolates from both 2010 and 2011, including K224/2011 from Kinango in Coast province and K98/2011 that grouped together with several others obtained from several districts around the southern and central parts of the Rift Valley province of the country (Fig. 1). They clustered together with others collected from Coast province in 2010, Central in 2005 and Nyanza in 2009. This lineage also contained three independently evolving sub-lineages (Fig. 2) with about $6 \%$ nucleotide differences among them.

The third lineage (B) within the EA-2 topotype included only one isolate fromin this study (K251/2010) (Fig. 2). This virus was collected from district 3 in the Western province of the country, near the border with Uganda (Fig. 1). It had 93\% nucleotide identity to viruses collected in 2002 from the same province in Kenya and 91-92\% identity with those from Eastern Uganda between 2002 and 2009 and about 99\% 
nucleotide identity with the 2011 viruses from the same region in Uganda (data not shown). However, this lineage had about $12 \%$ nucleotide difference from viruses in lineage A and about $12 \%$ from those in lineage $\mathrm{C}$ (within the VP1 coding region).

\section{Discussion}

This study has analyzed FMDVs isolated from serotype O FMD outbreaks in all the eight provinces_of Kenya from February 2010 until September 2011 that were responsible for the serotype OFMD-outbreaks during this period. Three independently evolving lineages belonging to topotype EA-2 were the most commonly occurring and found to be responsible for the majority of these recent outbreaks in Kenya. In addition, this study showed that there was another virus strain belonging to topotype EA-4 circulating in 2010 and that none of the recent viruses belonged to topotypes EA-1 and EA-3. Unlike two studies recently undertaken in neighboring Uganda (Kasambula et al., 2012; A. Namatovu , G. J. Belsham, C. Ayebazibwe, M.T. Dhikusooka, S. N. Wekesa, H. R. Siegismund, V. B. Muwanika, K. Tjørnehøj, unpublished results) which found only closely related serotype O FMDVs causing outbreaks, this study found different lineages even between neighbouring districts, indicative of different recent common introductions of the viruses. In addition, the different lineages were spread in several provinces of the country, suggestive of widespread transmission of the viruses within the country.

Viruses in lineage A consisted of several isolates that occurred late in 2010 and early 2011 that were distributed across 3 different regions of the country (Nyanza, Rift valley and Central). This group seems to have evolved from one recent common ancestor and within five months (December 2010 to April 2011), it had rapidly spread across a wide area within these three different-regions of Kenya. In particular, virus K24/2011 from Thika and K31/2011 from Kisumu were collected almost concurrently about $380 \mathrm{~km}$ rad distance-apart. yet they occurred almost concurrently. Furthermore, the period of - this occurrence coincided with two major national holidays and festive seasons (Christmas and Easter), during which animal movements for sale and slaughter are usually increased, which may explain the rapid spread. Considering that FMD control measures in Kenya mainly rely on animal movement control and vaccination, and that the virus had spread widely within a short period, it is likely that the control systems in the country were breached during this period. there were loopholes in the control systems in the country at that time. Similarly, lineage $\mathrm{C}$ viruses appear to have circulated across three different regions of Kenya 
that are also widely separated. Viruses within this lineage were obtained from different districts within the southern and central parts of the Rift Valley and the coastal region. In addition, it is noteworthy that this lineage contained three independently evolving sub-lineages, two of them in the Rift Valley and one in the Coast region. These observations are suggestive of inadequate countrywide disease control measures that ought to be investigated and addressed by the relevant authorities and stakeholders.

The Western regions of Kenya and Eastern parts of Uganda have traditionally been associated with movement of animals across the borders for various reasons including trade, grazing and cattle raiding. This probably is the reason why lineage B, including K251/2010 from this study collected in December 2010 from Kwanza district in western Kenya was eonfined toobserved in these two countries. This virus is closely related to an earlier virus from the same region in Kenya near the border with Uganda and other earlier viruses from Eastern Uganda. Furthermore, two other viruses recently isolated from Kumi and Bukedea districts in Eastern Uganda in March 2011 have been found to be closely related to this virus (A. Namatovu, G. J. Belsham, C. Ayebazibwe, M.T. Dhikusooka, S. N. Wekesa, H. R. Siegismund, V. B. Muwanika and K. Tjørnehøj, unpublished results). This is not surprising because, even though Kenya and Uganda are both East African countries, they have varying levels of disease control and biosecurity measures. Nevertheless, both countries use animal movement control as one of the methods of disease control. These findings have therefore-confirmed the transboundary mobility of serotype $\mathrm{O}$ as observed in a previous studies (Balinda et al., 2010a), hence necessitating enhancement of border surveillance and harmonization of livestock trade and animal movement regulations between the two countries if the much desired regional control of FMD is to be achieved.

Viruses belonging to topotype EA-4 have not been reported in Kenya previously but this topotype has been found in Ethiopia in 2005 (Ayelet et al., 2009) and earlier in Uganda in 1998-1999 (Ayelet et al., 2009; Balinda et al., 2010b). The identification of this topotype in Kenya in this study, unlike in previous studies, is probably due to the inclusion of a wider geographical representation of isolates in the present analysis that has additionally included the North-Eastern, Nyanza and Coastal provinces of Kenya. This finding is suggestive of a probable recent incursion of EA-4 into Kenya as an emerging topotype that needs to be thoroughly investigated. Consequently, this reveals that border disease control measures should be scrutinized and possible problems addressed. On the other hand, this virus may have been circulating 
earlier within the country undetected, therefore raising the need for regular surveillances and virus characterization to ascertain the strains of viruses in circulation.

By 2008, the EA-2 topotype had been found to be mainly confined to Uganda and Kenya for about ten years (Balinda et al., 2010b). This study has found that this topotype was the most commonly occurring in Kenya. This observation is largely consistent with previous studies in the East African region including Ethiopia, Kenya and Uganda (Ayelet et al., 2009; Balinda et al., 2010a) which indicated that recent FMDV $\mathrm{O}$ viruses in Kenya and Uganda are all grouped in topotype EA-2 and that there are hardly any incursions from outside the region. Apart from Kenya and Uganda, the EA-2 topotype has also been found in Burundi (1980, 1999 and 2003), the Democratic Republic of the Congo (2006 and 2010), Rwanda (1998 and 2004), Tanzania (1980, 1984, 1985, 1996, 1998, 2004, 2009 and 2012), northern Malawi (1998) and northern Zambia (2000 and 2010) (N.J. Knowles, unpublished data; Balinda et al., 2010a; Di Nardo et al., 2011) suggesting that EA-2 has been widespread in this region at least since the early 1980's. This is not unexpected as earlier studies have found these countries do rely strongly on one another for livestock trade (Rweyemamu et al., 2008) and pastures especially for the nomadic communities around the national borders. However, studies on the distribution of topotype EA-2 in the region as well as the other topotypes ought to be extended to other countries such as Burundi, Rwanda, Democratic Republic of Congo (DRC), Somalia and South Sudan where the FMD epidemiological situation is unclear

Topotype EA-3 was last documented in Kenya in 1999 (KEN/1/1999) and in the same year in Uganda (Balinda et al., 2010a), while in the recent past it has been mainly confined to Eritrea, Ethiopia and Sudan (Ayelet et al., 2009; Habiela et al., 2010). However, Di Nardo et al., (2011) have recently determined livestock movement patterns in the region indicating movements from Ethiopia, Sudan and Somalia into Kenya that may pose a risk of disease transmission in that direction. As a result the current confinement of EA-3 to these countries may not remain constant since this topotype could easily move back into Kenya if control measures at the borders are inefficient. Moreover, there is need for more surveillance in the Northern and North-Eastern parts of Kenya neighbouring these countries to ascertain the absence of this topotype within the country.

The majority of East African countries, including Kenya, rely on vaccination and animal movement control for FMD control measures. However, the current vaccine strain K77/1978 belongs to topotype EA-1 and 
has been used since 1981, not only in Kenya but also by several countries in the region such as Uganda, Ethiopia, Sudan, Burundi and Somalia. This study and other recent studies in Kenya (Balinda et al., 2010a), in Uganda (Kasambula et al., 2012; A. Namatovu, G. J. Belsham, C. Ayebazibwe, M.T. Dhikusooka, S. N. Wekesa, H. R. Siegismund, V. B. Muwanika and K. Tjørnehøj, unpublished results), in Ethiopia (Ayelet et al., 2009) and in Sudan (Habiela et al., 2010) have found that the VP1 coding region of this vaccine-which belongs to topotype (EA-1) strain has more than $15 \%$ nucleotide divergence, within the VP1 coding region, from the majority of the currently circulating strains. - The antigenic relationship between this vaccine strain and FMDV field strains has not been established, yet, as described by Paton et al., (2005), appropriate vaccine strain selection is essential for FMD control programs that depend on vaccination. Therefore, although vaccination failures have not been recently recorded, there is a need to undertake consistent PVM and vaccine matching.

In conclusion, the existing systems to control the spread of FMDV within Kenya and the entire region of Eastern Africa seem inadequate and require re-evaluation. Therefore, there is need for increased surveillance, better disease control measures at source and efficient animal movement control both within the country and across the borders. Additionally, it is necessary to undertake studies to assess the effectiveness of the current serotype $\mathrm{O}$ vaccine strains using virus neutralization tests or ELISAs as recommended by OIE (OIE, 2012).

\section{Acknowledgements}

The authors are grateful to the Director of Veterinary Services Kenya, Dr. Peter M. Ithondeka for allowing the use of the samples. Appreciation to Dr Kenneth Ketter for collating information on the samples, Dr. Eunice Chepkwony and the entire staff of the FMD Laboratory, Embakasi for their contribution in storage, packaging and transportation of the samples. We also appreciate the technical assistance from Jani Christiansen, Preben Normann and Tina Rasmussen at DTU Vet, Lindholm. We also thank Teddy Ochieng' and Margaret Mwangi of USAID, Kenya for their assistance in mapping. This work was supported by the Danish International Development Agency (DANIDA) under the Trans-boundary Animal Diseases in East Africa (TADEA) project, DFC no. 10-006KU. NJK and JW were partially funded by the Department for Environment, Food and Rural Affairs (Defra), UK (contract numbers SE2939 and SE2940). 


\section{Declaration of Conflict of Interest}

All authors declare that they have no conflict of interest. 


\section{References}

Alexandersen S., Mowat N. (2005) Foot-and-mouth disease: host range and pathogenesis. In 'Foot and mouth disease virus’: B. Mahy (Ed.), Springer - Verlag, Berlin, Heidelberg. Current Topics in Microbiology and Immunology, Vol. 288: 9-42.

Ayelet G., Mahapatra M., Gelaye E., Egziabher B.G., Rufeal T., Sahle M., Ferris N.P., Wadsworth J., Hutchings G.H., Knowles N.J. (2009) Genetic characterization of foot-and-mouth disease viruses, Ethiopia, 19812007. Emerg Infect Dis 15:1409-17.

Balinda S.N., Sangula A.K., Heller R., Muwanika V.B., Belsham G.J., Masembe C., Siegismund H.R. (2010a) Diversity and transboundary mobility of serotype $\mathrm{O}$ foot-and-mouth disease virus in East Africa: implications for vaccination policies. Infect Genet Evol 10:1058-65.

Balinda S.N., Siegismund H.R., Muwanika V.B., Sangula A.K., Masembe C., Ayebazibwe C., Normann P., Belsham G.J. (2010b) Phylogenetic analyses of the polyprotein coding sequences of serotype O footand-mouth disease viruses in East Africa: evidence for interserotypic recombination. Virol J 7:199.

Belsham G.J. (2005) Translation and replication of FMDV RNA. In 'Foot and mouth disease virus': B. Mahy (Ed.), Springer - Verlag, Berlin, Heidelberg. Current Topics in Microbiology and Immunology, Vol. 288: 43-70.

Di Nardo A., Knowles N.J., Paton D.J. (2011) Combining livestock trade patterns with phylogenetics to help understand the spread of foot and mouth disease in sub-Saharan Africa, the Middle East and Southeast Asia. Rev sci tech Off int Epiz 30:63-85.

Domingo E., Escarmis C., Baranowski E., Ruiz-Jarabo C.M., Carrillo E., Nunez J.I., Sobrino F. (2003) Evolution of foot-and-mouth disease virus. Virus Res 91:47-63.

Felsenstein J. (1985) Confidence limits on phylogenies: An approach using the bootstrap. Evolution 39:783-791.

Grubman M.J., Morgan D.O. (1986) Antigenic comparison of foot-and-mouth disease virus serotypes with monoclonal antibodies. Virus Res 6:33-43. 
Habiela M., Ferris N.P., Hutchings G.H., Wadsworth J., Reid S.M., Madi M., Ebert K., Sumption K.J., Knowles N.J., King D.P., Paton D.J. (2010) Molecular characterization of foot-and-mouth disease viruses collected from Sudan. Transbound Emerg Dis 57:305-14.

Hayama Y., Muroga N., Nishida T., Kobayashi S., Tsutsui T. (2012) Risk factors for local spread of foot-andmouth disease, 2010 epidemic in Japan. Res Vet Sci. 93:631-5

James A.D., Rushton J. (2002) The economics of foot and mouth disease. Rev Sci Tech 21:637-44.

Kasambula L., Belsham G.J., Siegismund H.R., Muwanika V.B., Ademun-Okurut A.R., Masembe C. (2012) Serotype Identification and VP1 Coding Sequence Analysis of Foot-and-Mouth Disease Viruses from Outbreaks in Eastern and Northern Uganda in 2008/9. Transbound Emerg Dis. 59 (4):323-30

Kitching R.P. (2002) Clinical variation in foot and mouth disease: cattle. Rev Sci Tech 21:499-504.

Knowles N.J., Samuel A.R. (2003) Molecular epidemiology of foot-and-mouth disease virus. Virus Res 91:6580.

Knowles N.J., Samuel A.R., Davies P.R., Kitching R.P., Donaldson A.I. (2001) Outbreak of foot-and-mouth disease virus serotype O in the UK caused by a pandemic strain. Vet Rec 148:258-9.

Mason P.W., Pacheco J.M., Zhao Q.Z., Knowles N.J. (2003) Comparisons of the complete genomes of Asian, $\underline{\text { African and European isolates of a recent foot-and-mouth disease virus type O pandemic strain }}$ (PanAsia). J Gen Virol 84 (6): 1583-1593.

Namatovu A., Wekesa S.N., Tjørnehøj K., Dhikusooka M.T., Muwanika V.B., Siegsmund H.R., Ayebazibwe C. (2013) Laboratory capacity for diagnosis of foot-and-mouth disease in Eastern Africa: implications for the progressive control pathway. BMC Veterinary Research 9: 19

OIE. (2012) Foot and mouth disease., (Office Internationale des Epizooties) manual of diagnostic tests and vaccines for terrestrial animals. Chapter 2.1.5 (http://www.oie.int/fileadmin/Home/eng/Health_standards/tahm/2.01.05_FMD.pdf). Accessed 20 ${ }^{\text {th }}$ May 2013.

Paton D.J., Valarcher J.F., Bergmann I., Matlho O.G., Zakharov V.M., Palma E.L., Thomson G.R. (2005) Selection of foot and mouth disease vaccine strains--a review. Rev sci tech Off int Epiz 24:981-93.

Perry B.D., Rich K.M. (2007) Poverty impacts of foot-and-mouth disease and the poverty reduction implications of its control. Vet Rec 160:238-41. 
Reid S.M., Grierson S.S., Ferris N.P., Hutchings G.H., Alexandersen S. (2003) Evaluation of automated RT- PCR to accelerate the laboratory diagnosis of foot-and-mouth disease virus. J Virol Meth 107: 129_ 139.

Roeder P., and Knowles N.J., (2009) Foot-and-mouth disease virus type C situation: the first target for eradication? In: The Global Control of FMD - Tools, Ideas and Ideals, Report of the Session of the Research Group of the Standing Technical Committee of EUFMD, 14-17 October 2008, Erice, Italy: FAO, Rome.

Rueckert R., Wimmer E. (1984) Systematic nomenclature of Picorna virus proteins. J. Virol 50:957-959.

Rweyemamu M., Roeder P., Mackay D., Sumption K., Brownlie J., Leforban Y., Valarcher J.F., Knowles N.J., Saraiva V. (2008) Epidemiological patterns of foot-and-mouth disease worldwide. Transbound Emerg Dis 55:57-72.

Saitou N., and Nei M. (1987) The neighbor-joining method: A new method for reconstructing phylogenetic trees. Mol Biol Evol 4:406-425.

Sakamoto K., Yoshida K. (2002) Recent outbreaks of foot and mouth disease in countries of east Asia. Rev sci tech Off int Epiz 21:459-63.

Samuel A.R., Knowles N.J. (2001a) Foot-and-mouth disease type O viruses exhibit genetically and geographically distinct evolutionary lineages (topotypes). J Gen Virol 82:609-21.

Samuel A.R., Knowles N.J. (2001b) Foot-and-mouth disease virus: cause of the recent crisis for the UK livestock industry. Trends Genet 17:421-4.

Sangula A.K., Siegismund H.R., Belsham G.J., Balinda S.N., Masembe C., Muwanika V.B. (2011) Low diversity of foot-and-mouth disease serotype $\mathrm{C}$ virus in Kenya: evidence for probable vaccine strain reintroductions in the field. Epidemiol Infect 139:189-96.

Shaw A.E., Reid S.M., Ebert K., Hutchings G.H., Ferris N.P., King D.P. (2007) Implementation of a one-step real-time RT-PCR protocol for diagnosis of foot-and-mouth disease. J Virol Methods 143:81-5.

Tamura K. P.D., Peterson N., Stecher G., Nei M., and Kumar S. (2011) MEGA5: Molecular Evolutionary Genetics Analysis using Maximum Likelihood, Evolutionary Distance, and Maximum Parsimony Methods. Mol Biol Evol 28: 2731-2739.

Thomson G.R., Vosloo W., Bastos A.D. (2003) Foot and mouth disease in wildlife. Virus Res 91:145-61. 
Vosloo W., Bastos A.D., Sangare O., Hargreaves S.K., Thomson G.R. (2002) Review of the status and control of foot and mouth disease in sub-Saharan Africa. Rev sci tech Off int Epiz 21:437-49.

2
3
4
5
6
7
8
9

7

8

10

11

12

13

14

15

16

17

18

19

20

21

22

23

24

25

26

27

28

29

30

31

32

33

34

35

36

37

38

39

40

41

42

43

44

45

46

47

48

49

50

51

52

53

54

55

56

57

58

59

60 


\section{List of figures and tables}

Fig. 1. Map of Kenya showing geographical districts and administrative regions (underlined) from which 2010-2011 samples analyzed in this study were collected. The encircled numbers correspond to the listing in Table 1.

Fig. 2. A Neighbor-joining tree based on nucleotide sequences of the VP1 coding region of serotype O viruses from Kenya in comparison with other East African topotypes. $(\bullet)$ indicates the 2010-2011 viruses in this study and ( $\boldsymbol{\Delta})$ the current vaccine strain. The values on the nodes show posterior probabilities. The encircled letters A-D show the lineages in which the recent Kenyan isolates group. EA -1 to 4 are the East Africa topotypes that have been found in Kenya.

Table 1. List of serotype O FMD viruses analyzed in this study, including viruses collected in Kenya during 2010-2011 and sequenced in this study, the current vaccine strain and other older viruses from Kenya and rest of the Eastern Africa region.

${ }^{\mathrm{a}} \mathrm{K}$ and KEN - prefixes used in FMDL Embakasi and at the Pirbright Institute, respectively for Kenyan isolates. ${ }^{\mathrm{b}}$ Current vaccine strain. 
Table 1. List of serotype O FMDV viruses analyzed in this study, including viruses collected in Kenya during 2010-2011 and sequenced in this study, the current vaccine strain and other older viruses from Kenya and rest of the Eastern Africa region.

\begin{tabular}{|c|c|c|c|c|c|c|}
\hline No. & Virus Ref. number $^{a}$ & Date collected & Country/Region/ District & Accession No. & Topotype & Reference \\
\hline 1 & K182/2010 & $26 / 08 / 2010$ & Kenya/Rift Valley/Laikipia & KF207885 & EA-2 & This Study \\
\hline 2 & K241/2010 & $17 / 12 / 2010$ & Kenya/Central/Thika-West & KF207886 & EA-2 & This Study \\
\hline 3 & $\mathrm{~K} 251 / 2010$ & $29 / 12 / 2010$ & Kenya/Western/Kwanza & KF207887 & EA-2 & This Study \\
\hline 4 & $\mathrm{~K} 24 / 2011$ & $04 / 02 / 2011$ & Kenya/Central/Thika & KF207881 & EA-2 & This Study \\
\hline 5 & $\mathrm{~K} 31 / 2011$ & $12 / 02 / 2011$ & Kenya/Nyanza/Siaya & KF207882 & EA-2 & This Study \\
\hline 6 & $\mathrm{~K} 38 / 2011$ & $02 / 03 / 2011$ & Kenya/Rift Valley/Rongai & KF207883 & EA-2 & This Study \\
\hline 7 & K47/2011 & $08 / 04 / 2011$ & Kenya/Rift Valley/Baringo & KF207884 & EA-2 & This Study \\
\hline 8 & KEN/1/2011 (K10/11) & $12 / 01 / 2011$ & Kenya/Central/Thika-West & KF135289 & EA-2 & This Study \\
\hline 9 & KEN/5/2011 (K32/11) & $15 / 02 / 2011$ & Kenya/Central/Nyandarua & KF135290 & EA-2 & This Study \\
\hline 10 & KEN/6/2011 (K33/11) & $19 / 02 / 2011$ & Kenya/Rift Valley/Rongai & KF135291 & EA-2 & This Study \\
\hline 11 & KEN/15/2011 (K91/11) & $18 / 09 / 2011$ & Kenya/Rift Valley/Gilgil & KF135292 & EA-2 & This Study \\
\hline 12 & KEN/16/2011 (K98/11) & $22 / 09 / 2011$ & Kenya/Rift Valley/ Masaba & KF135293 & EA-2 & $\begin{array}{l}\text { This Study } \\
\text { Kasambula et al., }\end{array}$ \\
\hline 13 & $\begin{array}{l}\text { UGA/APAC/2009 } \\
\mathrm{KEN} / 100 / 2010\end{array}$ & 2009 & Uganda/North/Apac & JN974309 & EA-2 & 2012 \\
\hline 14 & $\begin{array}{l}(\mathrm{K} 72 / 10) \\
\mathrm{KEN} / 137 / 2010\end{array}$ & $28 / 04 / 2010$ & Kenya/Rift Valley/ Eldoret & KF135281 & EA-4 & This Study \\
\hline 15 & $\begin{array}{l}(\mathrm{K} 152 / 10) \\
\mathrm{KEN} / 145 / 2010\end{array}$ & $06 / 07 / 2010$ & Kenya/Rift Valley/Transmara & KF135282 & EA-2 & This Study \\
\hline 16 & $\begin{array}{l}(\mathrm{K} 211 / 10) \\
\mathrm{KEN} / 146 / 2010\end{array}$ & $19 / 10 / 2010$ & Kenya/Rift Valley/Kericho & KF13528 & EA-2 & This Study \\
\hline 17 & $\begin{array}{l}(\mathrm{K} 220 / 10) \\
\mathrm{KEN} / 148 / 2010\end{array}$ & $16 / 11 / 2010$ & Kenya/Rift Valley/Nakuru & KF135284 & EA-2 & This Study \\
\hline 18 & $\begin{array}{l}(\mathrm{K} 222 / 10) \\
\mathrm{KEN} / 150 / 2010\end{array}$ & $17 / 11 / 2010$ & Kenya/Rift Valley/Rongai & KF135285 & EA-2 & This Study \\
\hline 19 & $\begin{array}{l}(\mathrm{K} 224 / 10) \\
\mathrm{KEN} / 151 / 2010\end{array}$ & $22 / 11 / 2010$ & Kenya/Coast/Kinango & KF135286 & EA-2 & This Study \\
\hline 20 & $\begin{array}{l}(\mathrm{K} 233 / 10) \\
\mathrm{KEN} / 152 / 2010\end{array}$ & $01 / 12 / 2010$ & Kenya/Rift Valley/Kajiado & KF135287 & EA-2 & This Study \\
\hline 21 & $(\mathrm{~K} 249 / 10)$ & $23 / 12 / 2010$ & Kenya/Rift Valley/Koibatek & KF135288 & EA-2 & This Study \\
\hline 22 & KEN/6/2009 (K16/09) & $01 / 02 / 2009$ & Kenya/Rift Valley/Kipkelion & KF135279 & EA-2 & This Study \\
\hline 23 & KEN/10/2009 (K29/09) & $01 / 02 / 2009$ & Kenya/Nyanza/Bondo & KF135280 & EA-2 & This Study \\
\hline 24 & $\mathrm{HKN} / 6 / 83$ & 1983 & Hong Kong & AJ294919 & CATHAY & Knowles et al., 2001 \\
\hline 25 & ISA $/ 8 / 83$ & 1983 & Indonesia & AJ303503 & ISA-1 & 2001 \\
\hline 26 & $\mathrm{~K} 1 / 2008$ & $08 / 01 / 2008$ & Kenya/Nairobi/Nairobi-East & HM756635 & EA-2 & Balinda et al., 2010 \\
\hline 27 & $\mathrm{KEN} / 3 / 2008(\mathrm{~K} 4 / 08)$ & $23 / 01 / 2008$ & Kenya/Central/Thika & KF135276 & EA-2 & This Study \\
\hline 28 & KEN/4/2008 (K6/08) & $06 / 02 / 2008$ & Kenya/Rift valley/Nakuru & KF135277 & EA-2 & This Study \\
\hline 29 & $\mathrm{~K} 11 / 2008$ & $20 / 02 / 2008$ & Kenya/Central/Kiambu-West & HM756637 & EA-2 & Balinda et al., 2010 \\
\hline 30 & $\mathrm{~K} 14 / 2008$ & $22 / 02 / 2008$ & Kenya/Rift Valley/Baringo & HM756638 & EA-2 & Balinda et al., 2011 \\
\hline 31 & K31/2008 & $05 / 05 / 2008$ & Kenya/Rift Valley/Kajiado & HM756639 & EA-2 & Balinda et al., 2012 \\
\hline 32 & $\begin{array}{l}\mathrm{K} 32 / 2008 \\
\mathrm{KEN} / 36 / 2008\end{array}$ & $05 / 05 / 2008$ & Kenya/Central/Thika & HM756640 & EA-2 & Balinda et al., 2013 \\
\hline 33 & (K104/08) & $01 / 12 / 2008$ & Kenya/Rift Valley/Molo & KF135278 & EA-2 & This Study \\
\hline 34 & K82/2007 & $01 / 10 / 2007$ & Kenya/Central/Murang'a & HM756634 & EA-2 & Balinda et al., 2010 \\
\hline 35 & $\mathrm{~K} 30 / 2007$ & $18 / 06 / 2007$ & Kenya/Rift Valley/Laikipia & HM756632 & EA-2 & Balinda et al., 2010 \\
\hline 36 & $\mathrm{~K} 2 / 2007$ & $11 / 01 / 2007$ & Kenya/Central/Kiambu & HM756629 & EA-2 & Balinda et al., 2010 \\
\hline 37 & KEN/12/2007 (K57/07) & $23 / 07 / 2007$ & Kenya/Eastern/Imenti-North & KF135275 & EA-2 & This Study \\
\hline 38 & KEN/4/2005 (K7/05) & $26 / 01 / 2005$ & Kenya/Central/Nyeri & KF135272 & EA-2 & This Study \\
\hline 39 & KEN/14/2005 (K48/05) & $21 / 07 / 2005$ & Kenya/Central/Kiambu & KF135273 & EA-2 & This Study \\
\hline 40 & $\begin{array}{l}\mathrm{KEN} / 27 / 2005(\mathrm{~K} 46 / 05) \\
\mathrm{KEN} / 24 / 2004\end{array}$ & $15 / 07 / 2005$ & Kenya/Central/Kiambu & KF135274 & EA-2 & This study \\
\hline 41 & $\begin{array}{l}(\mathrm{K} 139 / 04) \\
\mathrm{KEN} / 29 / 2004\end{array}$ & $30 / 07 / 2004$ & Kenya/Central,/Murang'a & KF135269 & EA-2 & This study \\
\hline 42 & $(\mathrm{~K} 170 / 04)$ & $21 / 10 / 2004$ & Kenya/Eastern,/Machakos & KF135270 & EA-2 & This study \\
\hline 43 & $\begin{array}{l}\text { KEN/30/2004 } \\
(\mathrm{K} 176 / 04)\end{array}$ & $24 / 12 / 2004$ & $\begin{array}{l}\text { Kenya/North- } \\
\text { Eastern/Marsabit }\end{array}$ & KF135271 & EA-2 & This Study \\
\hline 44 & KEN/3/2002 (K56/02) & $29 / 07 / 2002$ & Kenya/Western/Busia & KF135268 & EA-2 & This Study \\
\hline
\end{tabular}




$46 \mathrm{KEN} / 1 / 99(\mathrm{~K} 1 / 99) \quad 1999$

$47 \mathrm{~K} 50 / 2006 \quad 21 / 07 / 2006$

$48 \mathrm{~K} 31 / 2005 \quad 27 / 05 / 2005$

$49 \mathrm{~K} 79 / 2002 \quad 01 / 10 / 2002$

$50 \mathrm{~K} 114 / 1987$

$51 \mathrm{~K} 101 / 1980$

1987

1980

Kenya

Kenya

Kenya/Rift Valley/Uasin

Gishu

Kenya/Rift Valley/Laikipia

KF135266 EA-3 This Study

KF135267

EA-3 This Study

$52 \mathrm{~K} 83 / 1979$

1979

1978

1999

Kenya/Rift Valley/Nakuru

HM756626

EA-2 Balinda et al., 2010

HM756623 EA-2 Balinda et al., 2010

HM756616 EA-2 Balinda et al., 2010

Kenya

HM756594

Kenya

EA-2

Balinda et al., 2010

HM756589

Kenya/Central/Nyeri

AJ303511

EA-2

Balinda et al., 2010

Kenya/Rift Valley/Nakuru

HM756588

EA-1

Samuel and Knowles,

Uganda

HM756604

1996

Uganda

AJ296327

$01 / 12 / 2007$

$20 / 04 / 2005$

Ethiopia

FJ798139

Ethiopia

FJ798141

$20 / 04 / 2005$

Ethiopia

FJ798143

Ethiopia

HM211077

1995

Kenya

HM756601

Uganda

HM211075

Sudan

GU566054

Sudan

DQ165076

EA-1

2001

2004

1999

Sudan

DQ165075

EA-2

Balinda et al., 2010

Balinda et al., 2010

Samuel and Knowles,

EA-1 2001

EA-3 Ayelet et al., 2009

EA-4 Ayelet et al., 2009

EA-4 Ayelet et al., 2009

EA-2

EA-2

Balinda et al., 2010

EA-2

Balinda et al., 2010

EA-3

Balinda et al., 2010

1986

EA-3

Habiela et al., 2010

64 SUD/2/86

2006

Uganda/Mpigi

HM756627

EA-3

Habiela et al., 2010

Habiela et al., 2010

$65 \quad \mathrm{U} 18 / 2006$

2005

Uganda/Wakiso

HM756625

EA-2

Balinda et al., 2010

Uganda/Hoima

HM756620

EA-2

Balinda et al., 2010

${ }^{a} \mathrm{~K}$ and KEN are prefixes used in FMDL Embakasi and at the Pirbright Institute, respectively for Kenyan isolates; ${ }^{\mathrm{b}}$ Current vaccine strain. 


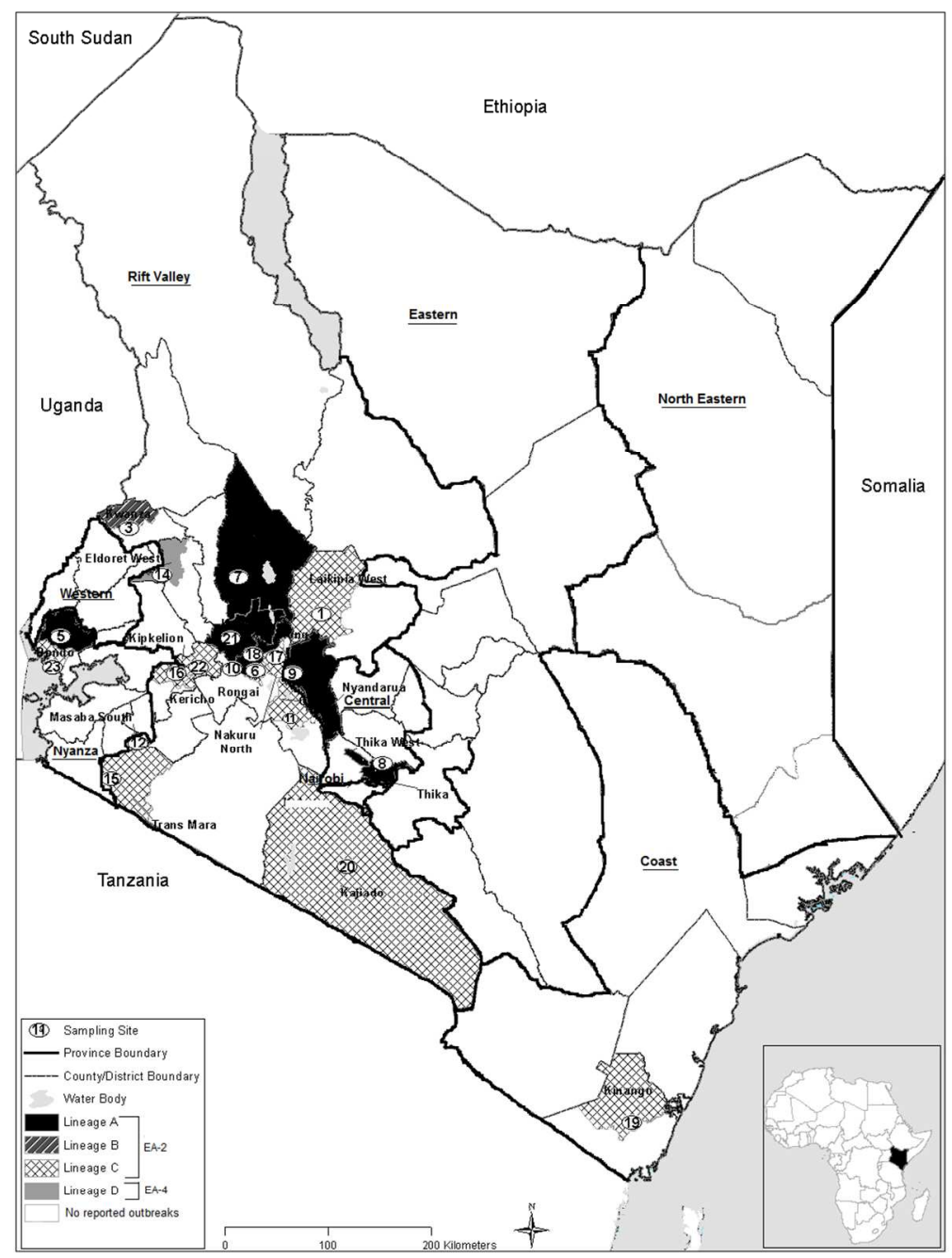

Fig. 1. Map of Kenya showing geographical districts and administrative regions (underlined) from which 2010-2011 samples analyzed in this study were collected. The encircled numbers correspond to the listing in Table 1.

$323 \times 437 \mathrm{~mm}(96 \times 96 \mathrm{DPI})$ 
Fig. 2. A Neighbor-joining tree based on nucleotide sequences of the VP1 coding region of serotype $O$ viruses from Kenya in comparison with other East African topotypes. $(\bullet)$ indicates the 2010-2011 viruses in this study and $(\boldsymbol{\Lambda})$ the current vaccine strain. The values on the nodes show posterior probabilities. The encircled letters A-D show the lineages in which the recent Kenyan isolates group. EA -1 to 4 are the East Africa topotypes that have been found in Kenya. $812 \times 1422 \mathrm{~mm}(96 \times 96 \mathrm{DPI})$ 